\title{
Dissociation of DNA from Histone by Reaction of Anti-cancer Drug cis-Diamminedichloroplatinum(II) with DNA-Histone Complexes Used as Cellular Model
}

\author{
Yuhki Koyama, Sachie Kikuchi, Sayaka NaKagawa, and Shigeki KobaYashi* \\ Division of Analytical Chemistry of Medicines, Showa Pharmaceutical University; 3-3165 Higashi-tamagawagakuen, \\ Machida, Tokyo 194-8543, Japan. Received June 6, 2006; accepted January 12, 2007
}

\begin{abstract}
Although both cis-diamminedichloroplatinum(II) (cisplatin or cis-DDP) and trans-diamminedichloroplatinum(II) bind to DNA, only cis-DDP is widely used as a chemotherapeutic agent; the stereoisomer trans-DDP is inactive. DNA, generally, is wound around the histone core in the nucleus of living cells and forms the nucleosome structure. To understand the essentially different anticancer activities of cis-DDP and trans-DDP, it is necessary to investigate the interaction of cis-DDP (or trans-DDP) with DNA around the histone in the nucleosome. Here, we used $\phi$ X174DNA-histone ${ }^{\text {LNCaP }}$ complexes prepared by the reaction of $\phi$ X174DNA with histone $^{\mathrm{LNCaP}}$ extracted from LNCaP cells. We first show that the ability of cis-DDP to dissociate the DNA from $\phi X 174 D N A-h i s t o n e^{\mathrm{LNCaP}}$, as a nucleosome model, is much stronger than that of trans-DDP. As a result of the action of cis-DDP, the DNA in the nucleosome is rendered naked, and the naked DNA is vulnerable to cisDDP (or other drugs). This study describes a new model showing that the difference in the activities of cis-DDP and trans-DDP is related to the difference in their abilities to dissociate the DNA from the nucleosome.
\end{abstract}

Key words cisplatin; anticancer drug; DNA-histone complex model; cisplatin modified DNA-histone complex; electron microscopy

cis-Diamminedichloroplatinum(II), $\mathrm{Pt}\left(\mathrm{NH}_{3}\right)_{2} \mathrm{Cl}_{2}$ (cisplatin or cis-DDP) is a useful anti-neoplastic agent in cancer chemotherapy. Many studies on the mechanism of this anticancer effect confirm that the bifunctional coordinate bonds between cis-DDP and cellular DNA are related to cell death. ${ }^{1,2)}$ However, the trans-isomer of cis-DDP is clinically ineffective although it binds to DNA. It is not yet clear why only cis-DDP is an antitumor drug., ${ }^{3,4)}$ One reason for this is that there is little information on tertiary structures of cisDDP-modified DNA-histone complexes produced by the reaction of cis-DDP with a nucleosome. When cis- or transDDP binds to a DNA-histone complex, it seems that the higher-order structure of the DNA undergoes marked changes. The structure of trans-DDP-modified DNA-histone complexes may differ from that of cis-DDP-modified DNA-histone complexes. In our previous paper, we reported that $c i s$-DDP is formed by change from negative $(-)$ to positive (+) writhing number $(\mathrm{Wr})$ binding to circular closed DNA. ${ }^{5}$ Moreover, we found that topologically invariant trefoil and catenane are produced by the reaction of cis-DDPmodified DNA with DNA topoisomerase I. ${ }^{6}$ Although the results suggest that similar products result from the binding of cis-DDP (or trans-DDP) with the DNA in cells, our previous model did not include histone-DNA complexes in the reaction model of $c i s$-DDP with DNA.

The non-histone proteins HMG1 and HMG2 belong to the HMG1-box protein family, which is known to bind to distorted DNA structures and to bend and unwind DNA upon binding. ${ }^{7,8)}$ In addition, it has recently been reported that the linker histone $\mathrm{H} 1$ also binds to cis-DDP-modified DNA and that the binding affinity of linker histone $\mathrm{H} 1$ is greater than those of HMG1 and HMG2. ${ }^{9)}$ To increase understanding of the differences in the conformational changes that occur on modification of DNA by cis-DDP and trans-DDP, the preparation of histone-DNA complexes and cis-DDP-modified histone-DNA adducts is necessary. Here, we prepared cis-
DDP-modified histone-DNA adducts using total core histones extracted from LNCaP cells. Our aim was to understand the topological difference between the structures of cisDDP- and trans-DDP-modified histone-DNA complexes which are shown in Fig. 1.

In this study, we show (i) the fiber-like structure model of the histone-DNA complexes prepared by the incubation of $\phi X 174 D N A$ with extracted core histones; and (ii) the change in DNA conformation that occurs on the binding of cis-DDP (and trans-DDP) with fiber-like DNA-histone complexes. The data on DNA length and topology obtained by electron microscopic analysis show that the action of $c i s$-DDP is to dissociate DNA from histone in DNA-histone complexes. However, trans-DDP had a smaller dissociating effect than cis-DDP. We think that the dissociation of DNA from DNA-histone complexes provides important information on the different chemical and chemotherapeutical functions of cis-DDP and trans-DDP. To help us increase our understanding of the action of cis-DDP in the nucleus, we used cisDDP- and trans-DDP-modified DNA-histone complexes as a cis-DDP- and trans-DDP-modified nucleosome model.

\section{Experimental}

Materials The platinum complexes, cis- and trans- $\mathrm{Pt}\left(\mathrm{NH}_{3}\right)_{2} \mathrm{Cl}_{2}$, were purchased from Sigma-Aldrich Japan Inc. (Tokyo). Closed circular supercoiled SV40 DNA and $\phi$ X174RF I DNA were from Gibco BRL (Rockville, MD, U.S.A.) and Takara Bio Inc. (Otu, Japan), respectively. Ethidium bromide and histone were from Sigma-Aldrich Japan Inc. and other chemicals were from Wako Pure Chemical Industries, Ltd. (Osaka, Japan).

Cell Lines and Cell Culture Human breast cancer MCF-7 and $\mathrm{LNCaP}^{10)}$ cells were obtained from Health Science Research Resources

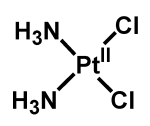

1
2

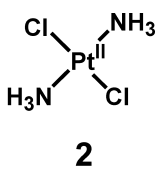

Fig. 1. Structures of Cisplatin (1) and Transplatin (2) 
Bank of Japan (Osaka, Japan) and Jikei University School of Medicine (Tokyo), respectively, and grown in phenol red-free RPMI1640 medium (Sigma, U.S.A.) containing $23.8 \mathrm{~mm} \mathrm{NaHCO}_{3}$ and supplemented with penicillin G (10000 units/1), streptomycin sulfonate $(10 \mathrm{mg} / 1)$, and $10 \%$ fetal calf serum (FCS) (JRH Biosciences, U.S.A.) and 10\% fetal bovine serum (FBS) (Sigma, U.S.A.). The cells were maintained in $75 \mathrm{~cm}^{2}$ culture flasks and incubated at $37^{\circ} \mathrm{C}$ in a humidified mixture of $5 \% \mathrm{CO}_{2}$ under atmospheric pressure. When the cell lines were used experimentally, they were first treated with trypsin-ethylenediaminetetraacetic acid (EDTA) (Cosmobio Co. Ltd, Japan) and then washed and resuspended in complete medium.

Histone Extraction from MCF-7 and LNCaP Cells Cultures allowed the cells in the confluent growth phase in a $75 \mathrm{~cm}^{2} \times 8$ culture flasks. The medium was replaced with (or without) $14 \mathrm{ml}$ of medium, and each flask was incubated for $24 \mathrm{~h}$. MCF-7 and LNCaP cells (about $3.2 \times 10^{8}$ cells/total) were harvested and collected by centrifugation $(5 \mathrm{~min}$ at $1000 \mathrm{rpm})$ and the pellets were washed twice with cooled $\operatorname{PBS}(-)$. Histone extracts were obtained according to the method of Cousens et al. ${ }^{11)}$ with minor modifications. The resulting precipitate was collected by centrifugation and dried in a vacuum for $5 \mathrm{~min}$, then dissolved in $500 \mu \mathrm{l}$ of $10 \mathrm{~mm}$ Tris- $\mathrm{HCl}$ (TH, pH 7.5) buffer and stored at $-20^{\circ} \mathrm{C}$. We refer to the histones extracted from $\mathrm{LNCaP}$ and MCF-7 cells as histone ${ }^{\mathrm{LNCaP}}$ and histone ${ }^{\mathrm{MCF} 7}$, respectively, and to commercial histone (purchased from Sigama) as histone ${ }^{\text {com }}$

Quantitative Analysis of Histone The concentration of histone proteins extracted from LNCaP and MCF-7 cells was determined using the modified Lowry method (Bio-Rad, U.S.A.).

Preparation of DNA-Histone Complexes The $\phi$ X174DNA-histone complexes were prepared by incubation of $10 \mathrm{mM} \mathrm{TH}$ buffer $(\mathrm{pH} 7.5)$ and $6 \mu \mathrm{l}$ of a solution containing $\phi X 174 \mathrm{DNA}(0.096 \mu \mathrm{g})$ with $2 \mu \mathrm{l}$ of a solution containing $0.556,1.13,2.01,4.53,9.05,18.1$, or $36.2 \mathrm{ng}$ of histone ${ }^{\mathrm{LNCaP}}$ at $37{ }^{\circ} \mathrm{C}$ for $40 \mathrm{~min}$. SV40 DNA-histone ${ }^{\mathrm{LNCaP}}$ complexes were prepared by a method similar to that described above. The $\phi \mathrm{X} 174 \mathrm{DNA}-$ histone ${ }^{\mathrm{MCF}} \mathrm{com}-$ plexes were prepared by incubation with $0.92,1.84,3.68,7.35,14.7,29.4$, or $58.8 \mathrm{ng}$ of histone $\mathrm{MCF}^{\mathrm{MC}}$. The mixtures were incubated for $60 \mathrm{~min}$ at $37^{\circ} \mathrm{C}$ and terminated at $-20^{\circ} \mathrm{C}$. The samples were analyzed by $0.8 \%$ agarose gel electrophoresis.

To confirm the results with SV40DNA and histones, we used the same method as that described above. SV40DNA-histone ${ }^{\mathrm{MCF} 7}$ complexes wer prepared by incubation of $10 \mathrm{mM}$ TH buffer $(\mathrm{pH} \mathrm{7.5)}$ and $6 \mu 1$ of a solution containing SV40DNA $(0.074 \mu \mathrm{g})$ with $2 \mu \mathrm{l}$ of a solution containing 0.115 , $0.231,0.461,0.923,1.845,3.69$, or $7.38 \mathrm{ng}$ of histone $\mathrm{LNCaP}^{\mathrm{L}}$ at $37^{\circ} \mathrm{C}$ for $60 \mathrm{~min}$. Similarly, SV40DNA-histone ${ }^{\mathrm{com}}$ complexes were prepared by incubation of $10 \mathrm{~mm}$ TH buffer ( $\mathrm{pH} 7.5)$ and $6 \mu \mathrm{l}$ of SV40DNA $(0.074 \mu \mathrm{g})$ with $2 \mu \mathrm{l}$ of histone ${ }^{\text {com }}$ solution containing $9.2,18.4,36.8,73.5,147,294$, and $588 \mathrm{ng}$ of histone $\mathrm{c}^{\mathrm{com}}$ at $37^{\circ} \mathrm{C}$ for $30 \mathrm{~min}$. The reactions were terminated at $-20^{\circ} \mathrm{C}$. The samples were analyzed by gel electrophoresis with $0.8 \%$ agarose.

Preparation of cis-DDP- (or trans-DDP)-Modified DNA-Histone Complexes A stock solution of cis-DDP $\left(2.5 \times 10^{-2} \mathrm{M}\right)$ was prepared by dissolving the complex in $10 \mathrm{~mm}$ TH buffer ( $\mathrm{pH} 7.5$ ). The cis-DDP-modified $\phi X 174 D N A-h i s t o n e^{\mathrm{LNCaP}}$ complexes were prepared by the incubation of $6 \mu \mathrm{l}$ of a solution containing $0.074 \mu \mathrm{g}$ of $\phi \mathrm{X} 174 \mathrm{DNA}-$ histone ${ }^{\mathrm{LNCaP}}$ complexes for $0,0.25,0.5,1.0,3.0,6.0,8.0,12.0,24.0,30.0,48.0$, or $72.0 \mathrm{~h}$ at a final concentration of $4.0 \times 10^{-5} \mathrm{M}$ of fresh cis-DDP with a solution (final volume $8 \mu \mathrm{l}$ ) containing $10 \mathrm{~mm} \mathrm{TH}$ buffer at $37^{\circ} \mathrm{C}$ and were stored at $-20^{\circ} \mathrm{C}$ in the dark. The reactions were terminated at $-20^{\circ} \mathrm{C}$ and analyzed by $0.8 \%$ agarose gel electrophoresis and electron microscopy.

Using a similar method, $\phi \mathrm{X} 174 \mathrm{DNA}-$ histone $\mathrm{LNCaP}^{\mathrm{LNC}}$ complexes were incubated with $2 \mu \mathrm{l}$ of trans-DDP for $0,0.25,0.5,1.0,3.0,6.0,8.0,12.0,24.0$, $30.0,48.0$, and $72.0 \mathrm{~h}$ at a final concentration of $4.0 \times 10^{-5} \mathrm{M}$ of fresh transDDP.

Electrophoresis The complexes were loaded on an $0.8 \%$ agarose gel for electrophoresis in TBE $(0.09 \mathrm{M}$ Tris-borate, $0.002 \mathrm{M}$ EDTA, $\mathrm{pH}$ 8.1) buffer at $15 \mathrm{~V}(1.5 \mathrm{~V} / \mathrm{cm})$ constant power for $16 \mathrm{~h}$. The gels were stained with ethidium bromide $(0.5 \mu \mathrm{g} / \mathrm{ml})$ for $1 \mathrm{~h}$ in TBE buffer, and photographed under UV light with a Polaroid camera using Polapan 667 films.

Electron Microscopy The treatment of samples used for electron microscopy was essentially the same as that described by Yamagishi. ${ }^{12)}$ The grids were inserted into a JEOL JEM-SCAN100CX II electron microscope, so that the shadowed surface, subjected to rotary shadowcasting with tungsten $(\mathrm{W})$, of the grid faced toward the emulsion side of the sheet film. Electron micrographs were taken at an initial magnification of $20000 \times$. The counter lengths of platinum-modified DNA-histone complexes were determined by tracing from negatives of the enlarged image and measured with a MicroAnalyzer version 1.1d (Nihon Poladigital, Ltd., Tokyo).

\section{Results}

Preparation of DNA-Histone Complexes with $\phi X 174 D N A$ and SV40 DNA To establish a simple means of preparing DNA-histone complexes, we investigated a method of incubating $\phi X 174 D N A$ (or SV40DNA) with histone $^{\mathrm{MCF} 7}$ (or histone ${ }^{\mathrm{LNCaP}}$ ) in $10 \mathrm{~mm}$ Tris- $\mathrm{HCl}$ buffer $(\mathrm{pH}$ 7.5). The $\phi X 174 \mathrm{DNA}-$ and SV40DNA-histone complexes were detected using $0.8 \%$ agarose gel electrophoresis, and the changes in electrophoretic mobilities as a function of the amount of histones are shown in Fig. 2.

Figure $2 \mathrm{~A}$ shows that the gel mobility of the bands decreased with increasing amount of histone ${ }^{\mathrm{LNCaP}}$; the amounts of histone ${ }^{\mathrm{LNCaP}}$ are shown in the upper part of the gels. A similar trend was also observed for the incubation of $\phi X 174 D N A\left(0.074 \mu \mathrm{g} /\right.$ tube) with histone ${ }^{\mathrm{MCF} 7}$ (Fig. 2B). The gel mobility of $\phi \mathrm{X} 174 \mathrm{DNA}-$ histones $^{\mathrm{MCF} 7}$ complexes decreased strikingly as the amount of histone ${ }^{\mathrm{MCF} 7}$ increased. This suggests aggregation of the $\phi X 174 \mathrm{DNA}-$ histone complexes. Therefore, electrophoretic mobility decreases toward the top of the gel (Figs. 2A, B, lanes $2-4$ and lanes $2-6$, respectively). However, the DNA-histone complexes indicated by the arrows are soluble complexes and the bands are shifted to the middle of the gels. The complexes are not aggregated like those at the top of the gel.

To confirm the formation of DNA-histone complexes, SV40DNA and SV40DNA-histone ${ }^{\text {com }}$ complexes were used as a comparison with $\phi X 174 \mathrm{DNA}-$ histones $^{\mathrm{LNCaP}}$ and $\phi X 174 D N A-$ histones $^{\mathrm{MCF} 7}$ complexes. SV40DNA was modified with the histone ${ }^{\mathrm{com}}$ and the SV40DNA-histone ${ }^{\mathrm{com}} \mathrm{com}$ plexes thus obtained were analyzed by $0.8 \%$ agarose gel electrophoresis (Fig. 3A). Figure 3B shows the changes in the electrophoretic mobility of the SV40DNA-histone ${ }^{\mathrm{MCF} 7}$ complexes prepared by the incubation of SV40DNA with histone ${ }^{\mathrm{MCF}}$. The striking decreases in the gel mobility of the SV40DNA-histone ${ }^{\mathrm{MCF} 7}$ and SV40DNA-histone ${ }^{\text {com }}$ complexes on addition of increasing amounts of histone are similar to those found with the $\phi \mathrm{X} 174 \mathrm{DNA}-\mathrm{histone}^{\mathrm{LNCaP}}$ and $\phi X 174 \mathrm{DNA}-$ histone ${ }^{\mathrm{MCF}}$ complexes.

Structure and Length of DNA-Histone Complexes We analyzed the length, size, and shape of the DNA-histone complexes using an electron microscope. Electron mi-
(A)

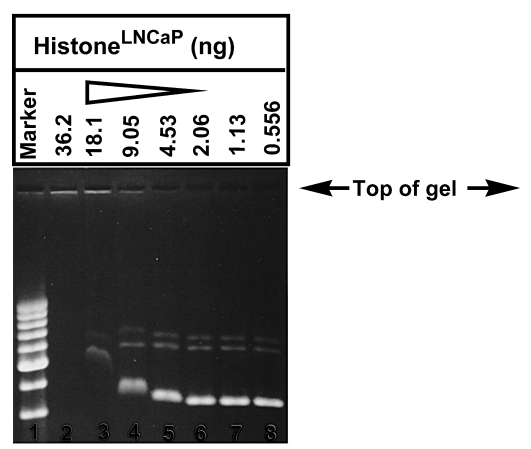

(B)

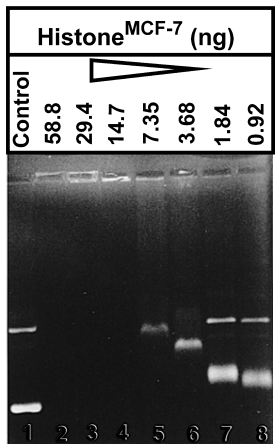

Fig. 2. Agarose Gel Electrophoresis of $\phi X 174 R F$ DNA-Histone Complexes Produced by Reaction of $\phi \mathrm{X} 174 \mathrm{RF}$ DNA with Histone Extracted from Cells

(A) Lane 1 shows a $1 \mathrm{~kb}$ DNA ladder marker. Lanes $2-7$ contain histone of 36.2 , $18.1,9.05,4.53,2.06,1.13$, and $0.56 \mathrm{ng}$, respectively. Mixtures of $\phi$ X174RF DNA $(0.074 \mu \mathrm{g})$ and histones ${ }^{\mathrm{LNCaP}}$ were incubated for $40 \mathrm{~min}$ at $37^{\circ} \mathrm{C}$. (B) Lane 1 contains $\phi X 174 \mathrm{RF}$ DNA $(0.074 \mu \mathrm{g})$. Lanes $2-7$ contain histones ${ }^{\mathrm{MCF} 7}$ of $58.8,29.4,14.7,7.35$, $3.68,1.84$, and $0.92 \mathrm{ng}$, respectively. 
croscopy visualization was performed by magnifying membranes fixed on solutions of DNA-histone complexes treated with formamide buffer $(20 \mathrm{~mm}$ TH, $2 \mathrm{~mm}$ EDTA, $50 \mathrm{v} / \mathrm{v} \%$ formamide) solution at $20000 \times$ or $28000 \times$. As the samples used for electron microscopy were treated with formamide buffer, the tertiary structure and interaction of the DNA-histone complexes would be expected to be destroyed because formamide is a denaturation reagent. However, the results of electron microscopy visualization indicated that the binding between the DNA and histone was strong. Figure 4 shows electron micrographs of the SV40DNA-histone ${ }^{\text {com }}$ (Fig. 4B) and $\phi \mathrm{X} 174 \mathrm{DNA}-$ histone $\mathrm{LNCaP}^{\mathrm{LN}}$ complexes (C) at different concentrations of the histones. The electron micrographs shown in Fig. 4Aia and ib correspond to SV40DNA only in lane 8 in Fig. 3A and $\phi X 174 D N A$ only in lane 1 in Fig. 2B, respectively. The electron micrograph shown in Fig. 4Biia corresponds to the sample tube of the gel in lane 5 (in Fig.

(A)

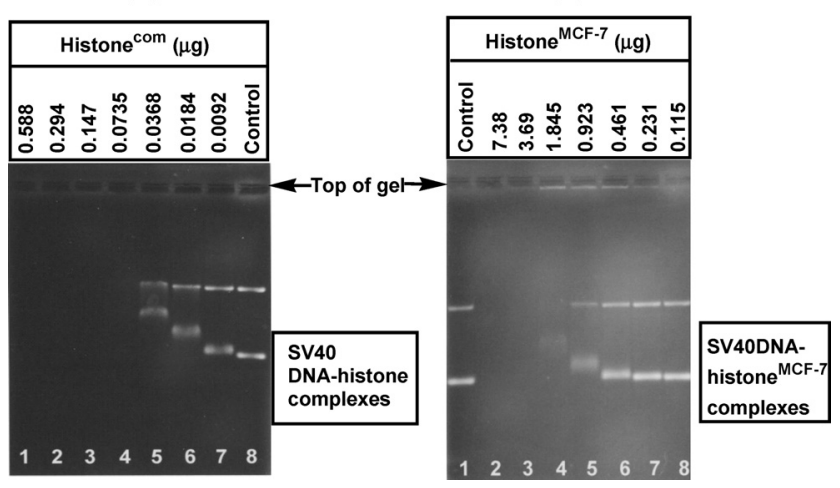

Fig. 3. Agarose Gel Electrophoresis of SV40DNA-Histone Complexes Produced by Reaction of SV40DNA with Histones Extracted from Cells

(A) Lanes $1-8$ contain SV40DNA $(0.063 \mu \mathrm{g})$. Lanes $1-7$ contain histones of 588 , $294,147,73.5,36.8,18.4$, and $9.2 \mathrm{ng}$, respectively. Mixtures of SV40DNA $(0.063 \mu \mathrm{g})$ and histones ${ }^{\mathrm{com}}$ were incubated for $30 \mathrm{~min}$ at $37^{\circ} \mathrm{C}$ and terminated at $-20^{\circ} \mathrm{C}$. (B) Lane 1 contains SV40DNA $(0.074 \mu \mathrm{g})$. Lanes $2-8$ contain histone ${ }^{\mathrm{MCF} 7}$ of $7.38,3.69,1.845$, $0.923,0.461,0.231$, and $0.115 \mu \mathrm{g}$, respectively. Histone ${ }^{\mathrm{MCF} 7}$ was extracted from MCF-7 cells.
3A) and the electron micrograph in Fig. 4Biib is an enlargement of that shown in Fig. 4Biia. The electron micrographs shown in Fig. 4Ciiia (and iiib) and iva (and ivb) correspond to the sample tubes of lanes 4 and 7 in Fig. 2A, respectively. From these electron micrographs, it is clear that the structures of the $\phi X 174 \mathrm{DNA}-$ histone ${ }^{\mathrm{LNCaP}}$ and SV40DNA-histone ${ }^{\text {com }}$ complexes are of folding, branched, and fiber-like shape. The fiber-like shape is very similar to the conformation published previously. ${ }^{13}$ These results indicate that the resulting complexes provide a simple model of the chromatin-like structure or a nucleosome-like structure such as that of the chromatin or nucleosome in the nucleus of the living cell. Although the controls of $\phi X 174 \mathrm{DNA}$ and SV40DNA are typically superherical and relaxed structures, as shown in Fig. $4 \mathrm{~A}$, the $\phi X 174 \mathrm{DNA}-$ histone ${ }^{\mathrm{LNCaP}}$ complexes show a branched conformation (Fig. 4C). Clearly, the shape of the complexes is different to that of $\phi \mathrm{X} 174 \mathrm{DNA}$.

To estimate the length of the $\phi X 174 D N A-$ histone $^{\mathrm{LNCaP}}$ complexes statistically, we measured the length of the DNA. Figure 5 shows the length distribution of the DNA in the samples corresponding to the gel lanes 4 and 7 in Figs. 2A and $\mathrm{B}$, respectively. By tracing from the negatives of the enlarged image $(\times 5)$, the lengths of the DNA and DNA-histone complexes were measured with a MicroAnalyzer. The mean length of $\phi X 174 \mathrm{DNA}$ was $1.70 \mu \mathrm{m}$ and the amount (n) of DNA observed was 166. It is clearly seen that the length of $\phi X 174 \mathrm{DNA}$ decreases with increasing amount of histone ${ }^{\mathrm{LNCaP}}$. In the gel lane 4 in Fig. $2 \mathrm{~A}$, the mean length of the $\phi X 174 D N A-$ histone ${ }^{\mathrm{LNCaP}}$ complexes $(\mathrm{n}=374$ molecules $)$ is $1.59 \mu \mathrm{m}$. The diagram has two peaks (mean $=0.95$ and $1.45 \mu \mathrm{m}$, respectively) and the modal value is $1.45 \mu \mathrm{m}$. The histgrams in Figs. 5A and $\mathrm{B}$ do not follow the normal distribution. The visualized $\phi X 174 \mathrm{DNA}-$ histone ${ }^{\mathrm{LNCaP}}$ complexes are compactly folded, as shown in the electron micrographs in Figs. 5A and B.

The results of the shape distribution of the fiber-like structures and the other topoisomers are listed in Table 1. Here, the shapes of the topoisomers $3,4, \mathrm{scc}$, and relaxed are equal
(A) ccDNA

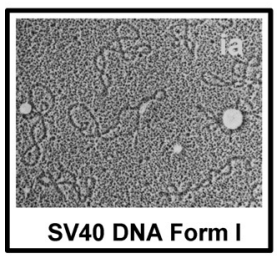
(B)

SV40 DNA-histone ${ }^{\text {com }}$ complexes

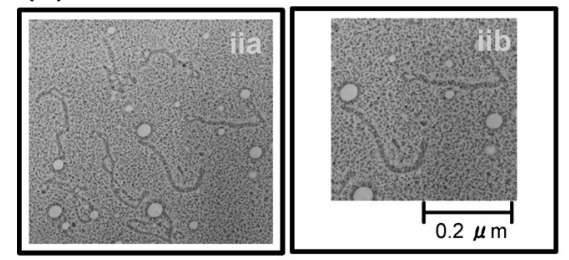

(C) $\phi X 174 R F$ DNA-histone ${ }^{\text {LNCaP }}$ complexes $^{a)}$

\section{(C-1) lane 4}

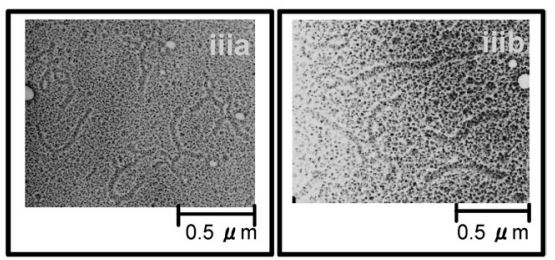

(C-2) lane 7

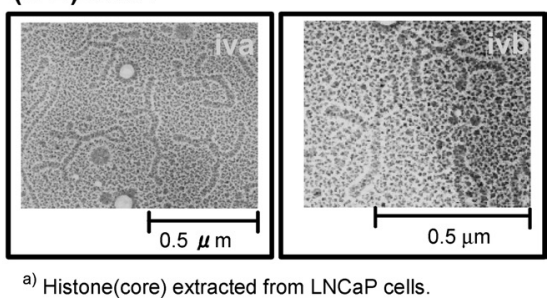

Fig. 4. Electron Micrographs of SV40DNA-Histone and $\phi$ X174DNA-Histone Complexes as a Model of Nucleosomes

(A) Electron micrographs of SV40DNA (ia) and $\phi$ X174DNA (ib) used in these studies. (B) Electron micrographs of SV40DNA-histone ${ }^{\mathrm{MCF} 7}$ complexes shown in lane 5 (iia and iib) in Fig. 3A. (C) Electron micrographs of $\phi X 174 \mathrm{DNA}-$ histone ${ }^{\mathrm{LNCaP}}$ complexes shown in lane 4 (iiia and iib) and lane 7 (iva and ivb) in Fig. $2 \mathrm{~A}$. Magnification $28000 \times$ or $20000 \times$. The bar represents the scale $(\mu \mathrm{m})$. 
Table 1. Shape Distribution of Fiber-Like Complexes Prepared by Reaction of Closed Circular DNA with Histone Extracted from Culture Cells

\begin{tabular}{|c|c|c|c|c|c|c|}
\hline \multirow[b]{2}{*}{ Type } & \multicolumn{5}{|c|}{ Shape distribution (\%) } & \multirow{2}{*}{$\begin{array}{c}\text { Total }(\%) \\
(\text { Amount })^{f)}\end{array}$} \\
\hline & $\begin{array}{c}\left.\text { Fiber-like }^{a}\right) \\
\text { structure }\end{array}$ & $\begin{array}{c}\text { Topo- } \\
\text { isomer }^{b)}(\mathbf{3})\end{array}$ & $\begin{array}{c}\text { Topo- } \\
\text { isomer }^{c)}(4)\end{array}$ & $\begin{array}{l}\text { Super- } \\
\text { coils }^{d)}\end{array}$ & $\begin{array}{l}\operatorname{Relax}^{e)} \\
\text { form }\end{array}$ & \\
\hline SV40-Histone ${ }^{\text {MCF7 g) }}$ & 70.5 & 7.6 & 7.4 & 10.6 & 3.9 & $100.0(488)$ \\
\hline$\phi \mathrm{X} 174$-Histone ${ }^{\mathrm{LNCaP} h)}$ & 62.5 & 9.4 & - & 22.2 & 5.3 & $99.4(941)$ \\
\hline$\phi \mathrm{X} 174$-Histone $\mathrm{L}^{\mathrm{LNCaP} i)}$ & 51.8 & 12.3 & 7.8 & 17.7 & 7.2 & $96.8(514)$ \\
\hline
\end{tabular}

a) See Fig. 5. b) DNA with one knot. c) DNA with two knots. d) DNA with three more knots. e) DNA without knot. $f$ ) Number of DNA observed by electron microscope. g) Histone ${ }^{\mathrm{MCF}}$ extracted from MCF-7 cells. h) Histone $\mathrm{e}^{\mathrm{LNCaP}}$ extracted from LNCaP cells. Lane 7 in Fig. 2A. i) Lane 4 in Fig. 2A.

(A)

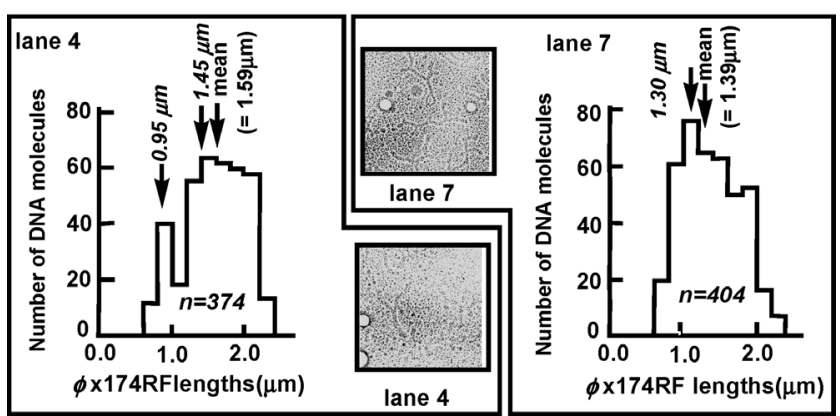

Fig. 5. Length Distribution of $\phi X 174 D N A-H i s t o n e^{\mathrm{LNCaP}}$ Complexes

(A) Length distribution of $\phi X 174 \mathrm{DNA}-$ histone $^{\mathrm{LNCaP}}$ complexes shown in lane 4 in Fig. 2A. Mean length is $1.59 \mu \mathrm{m}(\mathrm{n}=374 \mathrm{DNA}$ molecules). Two peaks occur in the length distribution: the molecule lengths at the peaks are 0.95 and $1.45 \mu \mathrm{m}$, respectively. (B) Length distribution of $\phi$ X174DNA-histone ${ }^{\mathrm{LNCaP}}$ complexes shown in lane 7 in Fig. 2A. Mean length is $1.39 \mu \mathrm{m}(\mathrm{n}=404$ DNA molecules). The length distribution shows one peak: the molecule length at the peak is $1.30 \mu \mathrm{m}$. The mean length of $\phi X 174 \mathrm{DNA}$ used in this study is $1.70 \mu \mathrm{m}$ ( $\mathrm{n}=166$ DNA molecules). All data shown in the histograms were obtained by electron microscopy.

to the topological shapes, $\square \mathrm{X},[\mathrm{W}$, superherical circular closed $(=\mathrm{scc})$, and $\square$, respectively. The knot number is one $(=3)$, two $(=4), \mathrm{N}(=\mathrm{scc})$, and zero (= relax), respectively. The distribution $(\%)$ was calculated as the ratio of ( $\mathrm{m}$ [measured amount of corresponding topoisomer] $/ \mathrm{n}$ [total DNA amount] $) \times 100$. Comparison of the results listed in Table 1 shows that the distribution ratio of the fiber-like structures is about $52-71 \%$ and we think that the winding of the histone $\mathrm{LNCaP}^{\mathrm{LN}}$ on the $\phi \mathrm{X} 174 \mathrm{DNA}$ is the major reaction under our experimental condition.

Preparation of cis-DDP- (or trans-DDP)-Modified DNA-Histone Complexes To understand the difference in the binding style of cis-DDP and trans-DDP to DNA-histone complexes, cis-DDP- (or trans-DDP)-modified $\phi \mathrm{X} 174 \mathrm{DNA}-$ histone $^{\mathrm{LNCaP}}$ complexes were prepared by incubation of fresh cis-DDP and trans-DDP (at final concentration of $\left.4.0 \times 10^{-5} \mathrm{M}\right)$ with $\phi X 174 \mathrm{DNA}-$ histone $\mathrm{LNCaP}^{\mathrm{L}}$ complexes (prepared under the same reaction condition as that used in lane 4 in Fig. 2A) in $10 \mathrm{~mm} \mathrm{TH}$ buffer. The reactions were time-dependent and were stopped by reducing the temperature to $-20{ }^{\circ} \mathrm{C}$. Figure 6 shows the results of $0.8 \%$ agarose gel electrophoretic analysis. In lane 6 in Fig. 6A, a marked change in the mobility of cis-DDP-modified $\phi X 174 D N A-h i s t o n e^{\text {LNCaP }}$ complexes can be seen after an incubation time of $3 \mathrm{~h}$. The mobility of the gel band is discontinuous between 1 and $3 \mathrm{~h}$. However, the mobility after a reaction of $3 \mathrm{~h}$ is almost flat against the top of the gel. On the other hand, such a drastic change was not observed in the reaction of trans-DDP (final concentration $4.0 \times 10^{-5} \mathrm{M}$ )
(A)

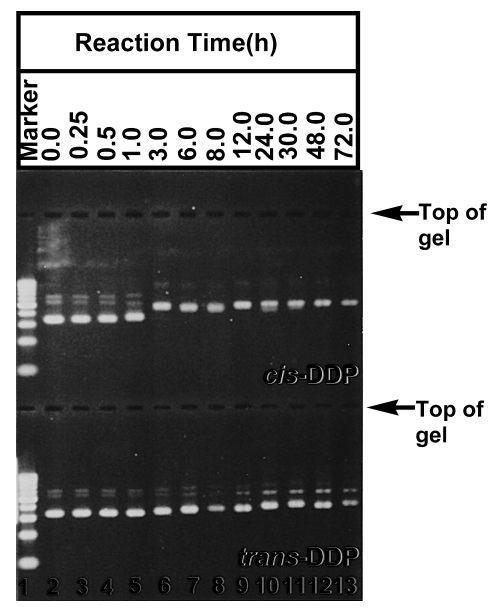

Fig. 6. Changes in Electrophoretic Mobility of (A) cis-DDP and (B) transDDP Modified $\phi$ X174DNA-Histone Complexes

(A and B) Lane 1 is a $1 \mathrm{~kb}$ DNA ladder marker. Lanes 2-13 each contain $\phi \mathrm{X} 174 \mathrm{DNA}-$ histone complexes prepared by reaction of $\phi \mathrm{X} 174 \mathrm{DNA}(0.074 \mu \mathrm{g})$ with histone $^{\mathrm{LNCaP}}$ prepared under the same conditions as those in Fig. 2A. The complexes were incubated in the presence of fresh cis-DDP (final concentration of $4.0 \times 10^{-5} \mathrm{M}$ ) (or trans-DDP) at $37^{\circ} \mathrm{C}$ for $0,0.25,0.5,1.0,3.0,6.0,8.0,12.0,23.0,30.0,48.0$, or $72.0 \mathrm{~h}$

with $\phi X 174 \mathrm{DNA}-$ histone $\mathrm{LNCa}^{\mathrm{LN}}$ complexes (lane 6 in Fig. 6B). The electrophoretic mobility of the trans-DDP-modified $\phi \mathrm{X} 174 \mathrm{DNA}-$ histone $^{\mathrm{LNCaP}}$ complexes is almost constant, as observed in lanes $2-13$.

The results are obviously different from those by incubation of $\mathrm{Pt}^{2+}$ (cis-DDP and trans-DDP) with DNA without histone demonstrated in our previous paper. ${ }^{5)}$ The electrophoretic mobility of $\phi \mathrm{X} 174 \mathrm{DNA}-$ histone $^{\mathrm{LNCaP}}$ complexes is discontinuous in time-dependent or concentration-dependent reactions with cis-DDP. The changes in gel mobility may be related to conformation changes occurring during interactions between cis-DDP and DNA-histone complexes. To confirm the cause of the discontinuous shift in the gel band, we analyzed the structure using electron microscopy.

Length and Structure of cis-DDP- (or trans-DDP)Modified DNA-Histone Complexes Figure 7 shows electron micrographs of the cis-DDP- (or trans-DDP)-modified $\phi \mathrm{X} 174 \mathrm{DNA}$-histone ${ }^{\mathrm{LNCaP}}$ complexes produced by incubation of cis-DDP (or trans-DDP) with $\phi \mathrm{X} 174 \mathrm{DNA}-$ histone $^{\mathrm{LNCaP}}$ complexes. In reactions of cis-DDP with $\phi \mathrm{X} 174 \mathrm{DNA}-$ histone $\mathrm{E}^{\mathrm{LNCP}}$ complexes for $0.25 \mathrm{~h}$, the complex is visualized as fiber-like DNA, as shown in the micrograph va in Fig. 7A (under the same reaction condition as that for lane 3 in Fig. 6). However, after a reaction for $6 \mathrm{~h}$ with cis-DDP, we observed that the $\phi X 174 \mathrm{DNA}$ in $\phi \mathrm{X} 174 \mathrm{DNA}-$ histone $^{\mathrm{LNCaP}}$ complexes of fiber-like shape was dissociated from the his- 

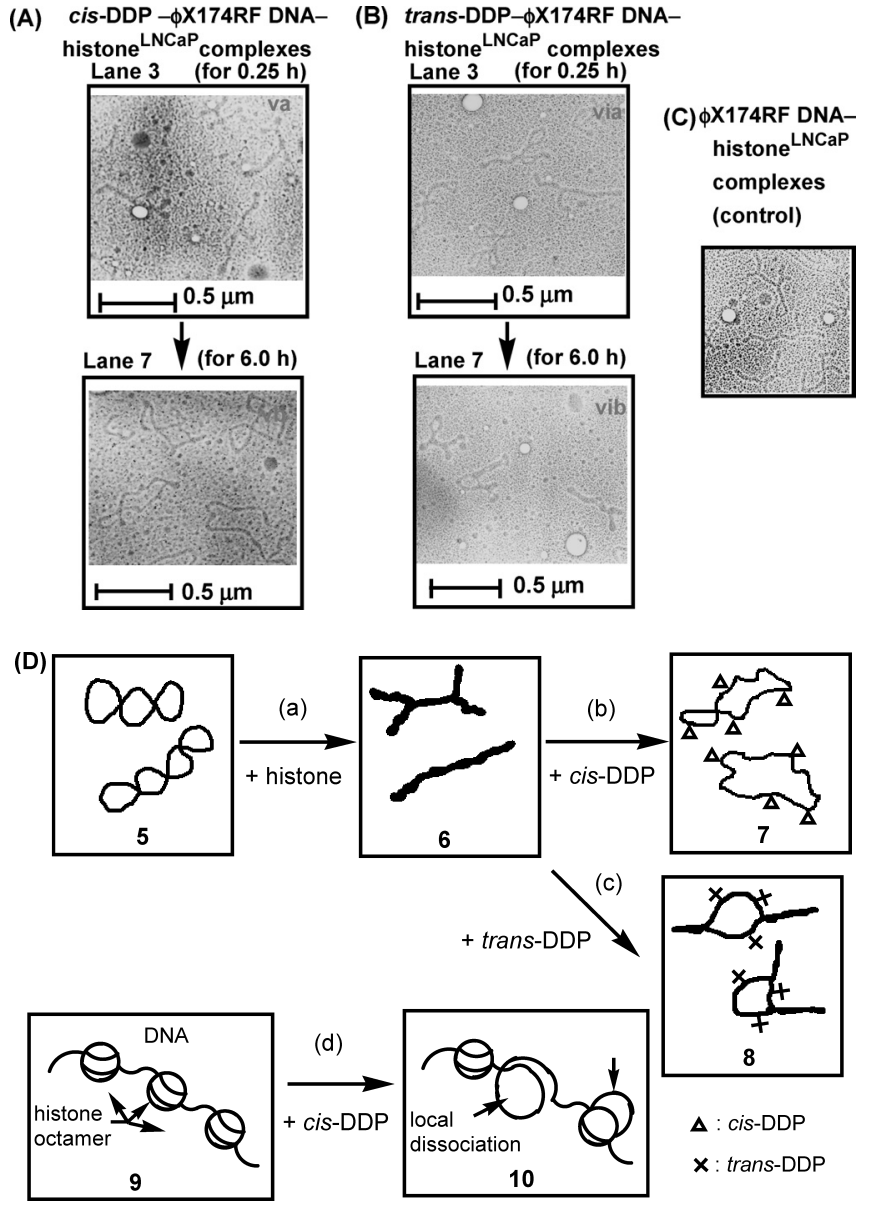

Fig. 7. Electron Micrographs of DNA Dissociated by Reaction of cis-DDP (or trans-DDP) with the Nucleosome Model (A, B, and C) and Illustration of Pathway of Dissociation of DNA

(A) Time course of the dissociation of $\phi X 174 \mathrm{DNA}$ from $\phi \mathrm{X} 174 \mathrm{DNA}-$ histone $\mathrm{LNCaP}^{\mathrm{L}}$ complexes by treatment of fresh cis-DDP (final concentration of $4.0 \times 10^{-5} \mathrm{M}$ ) for $0.25 \mathrm{~h}$ and 6.0 h, respectively: va, lane 3 (in Fig. 6A) and vb, lane 7 (in Fig. 6A). (B) Time course of the dissociation of $\phi$ X174DNA from $\phi$ X174DNA-histone ${ }^{\mathrm{LNCaP}}$ complexes by treatment with fresh trans-DDP for $0.25 \mathrm{~h}$ and $6.0 \mathrm{~h}$, respectively: via, lane 3 (in Fig. $6 \mathrm{~B}$ ); vib, lane 7 (in Fig. 6B). (C) $\phi$ X174DNA-histone ${ }^{\mathrm{LNCaP}}$ complexes (control). Mag nification is $28000 \times$ or $20000 \times$. The bar represents the scale $(\mu \mathrm{m})$. (D) The negative closed superherical $\phi \mathrm{X} 174 \mathrm{DNA}$ (5) used in this study is shown as an example. $\phi X 174 D N A-h i s t o n e^{\mathrm{LNCaP}}$ complexes (6) had a fiber-like shape resulting from the reaction of histone ${ }^{\mathrm{LNCaP}}$ with DNA 5 (path a). The dissociation of the DNA (7) occurred on addition to the complexes (6) of cis-DDP (path b). However, the dissociation of the DNA (8) on addition to the complexes (6) of trans-DDP was considerably less than that with cis-DDP (path c). A model of local dissociation (10) of DNA from the nucleosome (9) in living cells (path d). The bar represents the scale $(\mu \mathrm{m})$.

tone $\mathrm{L}^{\mathrm{LNCaP}}$ and unwound to the structure of the most relaxedlike DNA, as shown in micrograph vb in Fig. 7A (under the same reaction condition as that in lane 7 in Fig. 6A).

However, we found that $\phi X 174 \mathrm{DNA}$ almost dissociated from the histone ${ }^{\mathrm{LNCaP}}$ complexes in the reaction of transDDP with $\phi X 174 D N A-$ histone ${ }^{\mathrm{LNCaP}}$ complexes for $0.25 \mathrm{~h}$, as shown in the micrograph via in Fig. 7B (under the same reaction condition as that in lane 3 in Fig. 6B). In the reaction of trans-DDP with $\phi \mathrm{X} 174 \mathrm{DNA}-$ histone $^{\mathrm{LNCaP}}$ complexes for $6.0 \mathrm{~h}$ (under the same reaction condition as that in lane 7 in Fig. 6B), the dissociation of $\phi X 174 \mathrm{DNA}$ from the histone $\mathrm{LNCaP}^{\mathrm{Na}}$ much less than that of cis-DDP, as shown in micrograph vib in Fig. 7B. Micrograph vii shows $\phi X 174 D N A-$ histone ${ }^{\mathrm{LNCaP}}$ complexes as a control. The shapes of $\phi X 174 \mathrm{DNA}$ in micrographs via and vib are similar to those of the control $\phi \mathrm{X} 174 \mathrm{DNA}-$ histone $\mathrm{LNCaP}^{\mathrm{L}}$ com-
(A) Cis-DDP
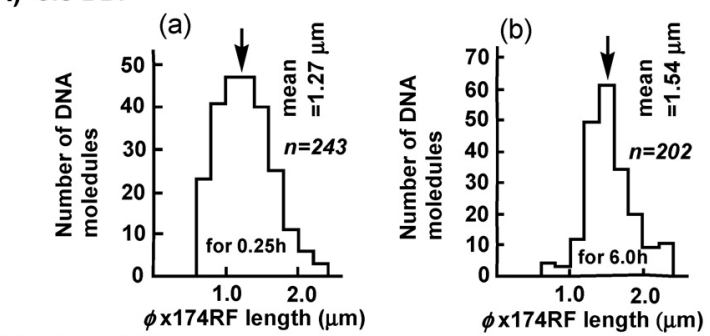

(B) Tra
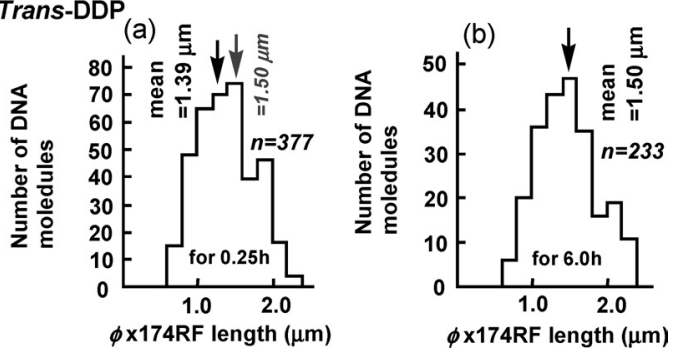

Fig. 8. Length Distribution of cis-DDP- and trans-DDP-Modified $\phi X 174 D N A-H i s t o n e^{\text {LNCaP }}$ Complexes

(A) (a) Length distribution of the $\phi X 174 \mathrm{DNA}-$ histone ${ }^{\mathrm{LNCaP}}$ complexes shown in lane 3 in Fig. 6A. Mean length is $1.27 \mu \mathrm{m}$ ( $\mathrm{n}=243$ DNA molecules). (b) Length distribution of the $\phi X 174 \mathrm{DNA}-$ histone ${ }^{\mathrm{LNCaP}}$ complexes shown in lane 7 in Fig. 6A. Mean length is $1.54 \mu \mathrm{m}(\mathrm{n}=202)$. (B) (a) Length distribution of the $\phi X 174 \mathrm{DNA}-$ histone ${ }^{\mathrm{LNCaP}}$ complexes shown in lane 3 in Fig. 6B. Mean length is $1.50 \mu \mathrm{m}(\mathrm{n}=377)$. (b) Length distribution of the $\phi \mathrm{X} 174 \mathrm{DNA}$-histone ${ }^{\mathrm{LNCaP}}$ complexes shown in lane 7 in Fig. $6 \mathrm{~B}$. Mean length is $1.50 \mu \mathrm{m}(\mathrm{n}=233)$. All data in the histograms were obtained by electron microscopy.

plexes (vii).

The lengths of $\phi X 174 D N A$ in cis-DDP and trans-DDP modified $\phi \mathrm{X} 174 \mathrm{DNA}$-histone $\mathrm{L}^{\mathrm{LNCaP}}$ complexes were measured using an electron microscope. The statistical result is summarized in Fig. 8. At time $0.25 \mathrm{~h}$ (lane 3 ) and $6.0 \mathrm{~h}$ (lane 7 ) in Fig. 6A, the mean length of the cis-DDP-modified DNA-histone complexes was 1.27 and $1.54 \mu \mathrm{m}$, respectively (Fig. 8A). The statistical difference is about $0.27 \mu \mathrm{m}(1.54$ $1.27 \mu \mathrm{m})$. Therefore, it can be seen that $\phi$ X174DNA molecule loosens and is long, and that the $\phi \mathrm{X} 174 \mathrm{DNA}$ is dissociated from the $\phi \mathrm{X} 174 \mathrm{DNA}-$ histone ${ }^{\mathrm{LNCaP}}$ complexes.

In the reaction of trans-DDP with $\phi$ X174DNA-histone ${ }^{\mathrm{LNCaP}}$ complexes, however, the difference in mean length was $0.11 \mu \mathrm{m}(1.50-1.39 \mu \mathrm{m})$ at times $0.25 \mathrm{~h}$ (lane 3$)$ and $6.0 \mathrm{~h}$ (lane 7) (Fig. 8Ba,b). In Fig. 8Ba, the statistical length of the DNA shows almost no changes since the difference in the mode and mean values of DNA length was about $0 \mu \mathrm{m}$ $(1.50-1.50 \mu \mathrm{m})$. The results suggest that trans-DDP has little ability to dissociate $\phi X 174 \mathrm{DNA}$ from $\phi \mathrm{X} 174 \mathrm{DNA}-$ histone $\mathrm{LNCaP}^{\mathrm{LN}}$ complexes.

\section{Discussion}

Our aim in this study was to elucidate the conformational changes in DNA that occur on the binding of cis-DDP and trans-DDP to DNA-histone complexes. Although cis-DDP or trans-DDP is bound to DNA-histone complexes in the nucleus, the conformational changes of the DNA remain uncertain. It is believed that the changes that occur in DNA structure are strongly related to the anti-cancer activity of cisDDP and trans-DDP. We describe here a new nucleus model using $\phi \mathrm{X} 174 \mathrm{DNA}$-histone complexes to improve our understanding of the roles of cis-DDP and trans-DDP in conformational changes in DNA. Many studies of the nucleus 
model using DNA-histone complexes have been performed by mixing histone $\mathrm{H} 1$ with DNA (and synthetic fragment DNA, etc..$^{13,14)}$ In our study, the DNA-histone complexes were prepared by reaction of $\phi X 174 \mathrm{DNA}$ with histones extracted from LNCaP and MCF-7 cells. In our analysis of the shapes and structures of $\phi X 174 \mathrm{DNA}-$ histone $^{\mathrm{LNCaP}}$, $\phi X 174 D N A-h i s t o n e^{\mathrm{MCF} 7}$, and SV40DNA-histone ${ }^{\mathrm{MCF} 7}$ complexes, electron microscopy visualization demonstrated the production of compact fiber-like DNA-histone complexes. Agarose gel electrophoresis also clarified the formation of DNA-histone complexes by a shift in electrophoretic mobility. The statistical analysis indicated that the fiber-like complexes were obtained with a yield of about $52-70 \%$. The shape of the fiber-like complexes is similar to that in the data of lit ${ }^{13)}$ produced by treatment of pBR322 DNA with histone H1. Thus, we have described a model of nucleosome-like complexes (Fig. 4C) obtained by incubation of $\phi X 174 D N A$ with histone ${ }^{\mathrm{LNCaP}}$ extracted from LNCaP cells. We think that the band at the top of the gel is formed by aggregation based on the interaction between DNA-histone complexes (lanes 2, 3 in Fig. 2). The band are insoluble. Thus, the production of DNA-histone complexes can be monitored as a gel shift.

To elucidate the change in DNA structure in the nucleus of cells, we performed an electrophoretic and electron microscopic study of cis-DDP- and trans-DDP-modified DNA by the reaction of cis-DDP and trans-DDP with DNA-histone complexes in a nucleosome model. Electron microscopic visualization showed that cis-DDP is able to dissociate the DNA from DNA-histone complexes. Evidently, $\phi$ X174DNA easily dissociates from $\phi \mathrm{X} 174 \mathrm{DNA}-$ histone $\mathrm{LNCaP}^{\mathrm{LN}}$ complexes (Figs. 7A, B). Therefore, the large changes in gel mobility, which can be observed in lanes 5 and 6 in Fig. 6A may be related to the dissociation of $\phi \mathrm{X} 174 \mathrm{DNA}$ from the complexes. However, such an inflection point is not observed on the gel electrophoresis shown in Fig. 6B. Lanes 5 and 6 in Fig. 6B suggest that trans-DDP modified $\phi X 174 D N A-$ histone ${ }^{\mathrm{LNCaP}}$ complexes are not dissociated to trans-DDP modified $\phi X 174 D N A$ and histone ${ }^{\mathrm{LNCaP}}$. Electron microscope visualization supports the idea that the complexes do not contribute to the dissociation of trans-DDP modified $\phi \mathrm{X} 174 \mathrm{DNA}$ and histone ${ }^{\mathrm{LNCaP}}$.

A similar result was observed in SV40DNA-histone ${ }^{\mathrm{MCF} 7}$ complexes prepared by incubation of histone ${ }^{\mathrm{MCF} 7}$ extracted from MCF-7 cells with SV40DNA. Although the dissociation of DNA from DNA-histone complexes (6) is accelerated by cis-DDP binding (path $\mathrm{b}$ in Fig. 7D), the geometrical isomer, trans-DDP, delays the dissociation of DNA from DNA-histone complexes, as shown in path $\mathrm{c}$ in Fig. 7D. The evidence suggests that DNA is locally dissociated from the nucleosome attacked by cis-DDP (path $d$ in Fig. 7D). We think that DNA (10) locally dissociated from histone octamer may exist in the nucleus of living cells. Our results are rele- vant to the understanding of the difference in biological efficacy between trans-DDP and cis-DDP-modified DNA-histone complexes. Many studies have used cis-DDP- or transDDP-modified DNA as study material. However, we have pointed out the importance of DNA-histone complexes as the cellular target for $c i s$-DDP.

\section{Conclusion}

We prepared $\phi \mathrm{X} 174 \mathrm{DNA}$-histone complexes by reaction of histone extracted from LNCaP and MCF-7 cells with $\phi X 174 D N A$ and SV40DNA. These complexes may provide a simple model system for the nucleosome which has a fiberlike structure. Using DNA-histone complexes, we found that the binding interaction of cis-DDP, an anti-cancer drug, with DNA is able to dissociate the DNA from DNA-histone complexes more easily than trans-DDP. In living cells, the easy local disassociation of DNA from the nucleosome may be an important aspect of the anit-cancer activity of cis-DDP in both biophysical and chemotherapeutic processes. Finally, we think that it would be useful to increase our understanding of changes in DNA structure in the reactions of cis-DDP and trans-DDP with $\phi \mathrm{X} 174 \mathrm{DNA}-$ histone complexes as a nucleosome model and to develop more active analogs of $c i s$-DDP and other metals.

\section{References}

1) Rosenberg B., "Chemistry and Biochemistry of a Leading Anticancer Drug," ed. by Lippert B., Wiley-VCH, Zürich, 1999, pp. 3-30.

2) Montero E. I., Perez J. M., Schwartz A., Fuertes M. A., Malinge J. M., Alonso C., Leng M., Navarro-Ranninger C., Chembiochem, 3, 61-67 (2002).

3) Zwelling L. A., Kohn K. W., Cancer Treatment Reports, 63, 1439 1444 (1979).

4) Reedijk J., Pure Appl. Chem., 59, 181-192 (1987).

5) Kobayashi S., Nakamura N., Maehara T., Hamashima H., Sasatsu Y., Asano K., Ohishi Y., Tanaka A., Chem. Pharm. Bull., 49, 1053-1060 (2001).

6) Kobayashi S., Furukawa M., Dohi C., Hamashima H., Arai T., Asano K., Tanaka A., Chem. Pharm. Bull., 47, 1053-1060 (1999).

7) Pil P. M., Lippard S. J., Science, 256, 234-237 (1992).

8) Ohndorf U. M., Rould M. A., He Q., Pabo C. O., Lippard S. J., Nature (London), 399, 708-712 (1999).

9) Yaneva J., Leuba S. H., van Holde K., Zlatanova J., Proc. Natl. Acad. Sci. U.S.A., 94, 13448-13451 (1997).

10) Horoszewicz J. S., Leong S. S., Kawinski E., Karr J. P., Rosenthal H., Chu T. M., Mirand E. A., Murphy G. P., Cancer Res., 43, 1809-1818 (1983).

11) Cousens L. S., Gallwitz D., Alberts B. M., J. Biol. Chem., 254, 17161723 (1979).

12) Yamagishi H., "Chemistry of Nucleic Acid II," ed. by The Japanease Biochemical Society, Tokyo Kagaku Dojin, Tokyo, 1989, p. 389.

13) Sogo J., Stasiak A., DeBernardin W., Losa R., Koller T., "Electron Microscopy in Molecular Biology," ed. by Sommerville J., Scheer U., IRL Press, Oxford, 1987, pp. 61-79.

14) Buttinelli M., Leoni L., Sampaolese B., Savino M., Nucleic Acids Res., 19, 4543-4549(1991). 